\title{
Morphological characterization and germination of Syagrus schizophylla (Mart.) Glass. (ARECACEAE)
}

\author{
Rômulo André Beltrame*, Janie Mendes Jasmim, Henrique Duarte Vieira
}

State University of North Fluminense

${ }^{*}$ Corresponding author, e-mail: romuloagronomia@hotmail.com

\begin{abstract}
The interest in Syagrus schizophylla as an ornamental palm tree and the demand for conservation and preservation of the species led to this research. The objective was to study the physiological characteristics of its germination at different temperatures, as well as the morphological and biometrical characterization of diaspores and seedlings at the initial stages of growth and development. The research was divided into two experiments. In the first one, the aim was to identify the water absorption phases of seeds during germination under five scarification treatments as follows: intact diaspores, scarified diaspores, diaspores with endocarp rupture and intact seeds. In the second experiment, germination was tested at 25,30 e $25-35{ }^{\circ} \mathrm{C}$; the first germination count, seedling emergence, abnormal seedlings, non-germinated seeds, the emergence curve, the emergence speed index and the mean time of emergence were evaluated. Afterwards, the morphological and biometrical characteristics of diaspores and seedlings were described. The water absorption curve observed under the different scarification treatments showed different water absorption patterns. Emergence percentages were 53, 61 and $47 \%$ at 25,30 and $25-35{ }^{\circ} \mathrm{C}$, respectively. The highest emergence speed index was obtained at $30^{\circ} \mathrm{C}$. The mean time of emergence was 30 days, approximately, under all the temperatures tested. The diaspores showed a great variability in both shape and size, presenting a globular to ovoid shape with an average length of $2.44 \mathrm{~cm}$ and an average width of $1.39 \mathrm{~cm}$. The germination can be classified as hypogeal crypto cotyledonal of the remote-tubular type.
\end{abstract}

Keywords: seed, licuriroba, palm tree, temperature, morphology

\section{Introduction}

The seed represents the key structure in the life cycle of most plants through which the dispersal and perpetuation of species occur (Maia et al., 2014). Seeds represent the main means of plant regeneration, they are used as food for humans and animals. Thus, studies about seeds are indispensable.

Syagrus schizophylla (Mart.) Glass. is a terrestrial palm tree with high ornamental potential. It is popularly known in different areas of occurrence as licuriroba, aricuriroba, nicuriroba, coco-babão and coco-caboclo. The species is endemic to Brazil, belongs to the Arecaceae family and is widespread in the

Northeast, being found in the states of Alagoas, Bahia, Pernambuco and Sergipe, mostly in sandy coastal areas (Restinga) and in the Atlantic Tropical Rainforest biome (Leitman et al., 2015).

Due to the increased intensity of native forests fragmentation caused by excessive exploitation of natural resources and the growth of urban and touristic pressure in its habitat, $S$. schizophylla has been listed by Centro Nacional de Conservação da Flora (CNCFlora) as a potentially endangered species (Prieto \& Messina, 2012). Thus, studies that envisage determining suitable conditions for the germination of its seeds, such as the effects of temperature, can give invaluable information about the propagation 
and physiology of the species contributing for its conservation and preservation.

Seeds of most palms show morphophysiological dormancy, mainly related to the embryo immaturity and to the endocarp impermeability (Baskin \& Baskin, 2014). Recent studies with palms from the Brazilian tropical savanna (Cerrado) reported their non-profound physiological dormancy (Neves et al., 2013; Ribeiro et al. 2011), which was related to the difficulty in embryo histodifferentiation due to the amount of reserves and to the structural resistance of adjacent tissues (Carvalho et al. 2015).

In Brazil, the methodology for germination tests is described in handbooks for seed analyses (Brasil, 2009). Nevertheless, only a few palm species have validated tests, which are almost always restricted to the species of interest for producing oil, heart of palm and similar products. Methodologies for $S$. schizophylla are not available, thus reinforcing the need for research on its germination physiology that might enable advances in its domestication and on commercial use of the species.

The interest in S. schizophylla as an ornamental palm tree and the demand for conservation and preservation of the species led to this research, whose objective was to study the physiological characteristics of its germination at different temperatures, as well as the morphological and biometrical characterization of diaspores and seedlings at the initial stages of growth and development.

\section{Material and methods}

Fruits of S. schizophylla were manually harvested, after seed physiological maturation, that is, seeds from yellow or red fruits, according to the recommendation of Pivetta et al. (2005), from palm trees on the farm of Tropical Plantas, a commercial nursery located at Rodovia Anhanguera, $\mathrm{km} \mathrm{43}$, in Limeira, in the State of São Paulo, approximate coordinates $22^{\circ} 35^{\prime}$ South latitude and $47^{\circ} 21^{\prime}$ 'West longetude. The fruits were then submerged in water for 72 hours and the diaspores were extracted from the fruits by friction with a pulper, and manual removal with the aid of a scalpel. After that, the diaspores were sent to the laboratory for carrying out the research.

Determination of the water absorption curve was performed according to methodology proposed by Baskin and Baskin (2001). The experiment was carried out in a completely randomized block design (CRB), with four replicates of 25 of intact diaspores (T1), diaspores with scarified endocarp (T2), diaspores with ruptured endocarp (T3) and intact seeds (diaspores whose endocarp was removed) (T4) were put into beakers containing $150 \mathrm{~mL}$ of distilled water and kept at $30^{\circ} \mathrm{C}$ in a germination chamber with photoperiod of 8 hours of light and 16 hours of darkness. In the present paper difference was made between diaspores and seed: diaspores being the seeds with endocarp; and seeds being the seeds themselves. Diaspores were scarified with sand paper opposite to the operculum till perforation of the endocarp without damaging the seed; the rupture of the endocarp was achieved by clamping the diaspores with a bench vise; and the intact seeds were extracted from the endocarp with a scalpel. The water was changed every $24 \mathrm{~h}$ and the water volume in the beakers was replenished as often as necessary to complete $150 \mathrm{~mL}$ of distilled water. The weighing of the diaspores and seeds was carried out at the beginning of the experiment (time zero) and at pre-established intervals: every two hours in the first six-hour-interval, at the $12^{\text {th }}$ and the $24^{\text {th }}$ hour, and every 24 hours after that, until imbibition stabilization was observed, which occurred on the $28^{\text {th }}$ (672 hours) after the beginning of the experiment. Diaspores and seeds were removed from the water and had their surfaces thoroughly dried with absorbing paper before weighing; a digital balance $(0.001 \mathrm{~g}$ precision) was used for this purpose; after weighing the diaspores and seeds were put into the water again. The moisture content of the diaspores and seeds was calculated on a wet basis (Brasil, 2009).

For the evaluation of the effect of temperature on the emergence S. schizophylla seedlings, diaspores had their endocarps ruptured with the aid of a bench vise and subjected to a pre-hydration by imbibition in distilled water for $72 \mathrm{~h}$ at $30{ }^{\circ} \mathrm{C}$, according to the standard pre-established by the imbibition 
curve. Diaspores were sown in perforated plastic trays $(30 \times 15 \times 5 \mathrm{~cm})$ containing washed sand moisturized with distilled to reach $80 \%$ of its water retention capacity, at approximately three centimeters of depth. Sand moisture was maintained by difference in tray weight plus dry sand and saturated with water. After sowing, the trays were kept in separate BOD growing chambers regulated at constant 25 and $30{ }^{\circ} \mathrm{C}$ and alternated $25-35{ }^{\circ} \mathrm{C}$, with a photoperiod $8 / 16$ h for 90 days. The experiment was carried out in a completely randomized block design (CRB), with four replicates of 25 seeds each.

Emergence was checked daily until it remained constant, which was observed at 45 DAS. The emergence speed index (ESI) was calculated as described by Maguire (1962): ESI $=N_{1}+N_{2} \ldots N_{i} / D_{1}+D_{2} \ldots D_{i^{\prime}}$ being $N_{1}+N_{2} \ldots$ $N_{i}$ the number of emerged seedlings at first, second and $i^{\text {th }}$ count, respectively; $D_{1}+D_{2} \ldots D_{i}$ the number of days at first, second, ... ith count, respectively. The first germination count was carried out concomitantly with the germination test; the number of germinated seeds at first count was the number of germinated seeds considering those presenting protrusion of the cotyledon petiole, which was registered on the $21^{\text {st }}$ DAS. The mean time of emergence (MTE) was calculated using the equation proposed

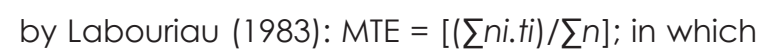
$n i$ is the number of germinated seeds at a time interval, $n$ the total number of emerged seedlings and ti emergence days.

On the $90^{\text {th }}$ DAS the number of normal and abnormal seedlings, as well as the number of non-germinated seeds, were registered as described in Brasil (2009), and the results were expressed in percentages. Data were subjected to analysis of variance and the means compared by Tukey test at $5 \%$ probability using the software R Core Team.

The morphological and biometrical characterization of the diaspores was based on 60 and 100 units, respectively. The biometry of diaspores was carried out with a digital caliper (0.1 mm precision) for measuring the length, from apex to base, and the width on the equatorial part of the diaspores. The observations were made with the naked eye and with a magnifying glass. The statistical parameters for analysis of biometrical data were the mean, standard deviation and coefficient of variation.

The seedlings were obtained adopting the same methodology described for the germination test. Evaluations of seedlings were made at 15,30, 45 and 60 DAS. Nevertheless, after germination, daily observations were carried out as new structures emerged. The growth and development of seedlings and root, and the development of color were observed. Fifteen normal healthy seedlings were used for the descriptions.

The terminology used for the morphological characterization was based on the descriptions of Batista et al. (201 1a); SantosMoura et al. (2016); Viji et al. (2015) and Tomlinson (1960, 1961). The images were edited with the software Adobe Photoshop CS6.

\section{Results and discussion}

The results obtained from freshly harvested seeds revealed diaspore moisture contents of $19.89 \%$ and the weight of 1000 diaspores (WTD) was $3.65 \mathrm{~kg}$. The WTD gives an idea of seed size, of its level of maturation and sanitary status (Brasil, 2009).

Intact diaspores (T1), diaspores with scarified endocarp (T2), and diaspores with endocarp rupture (T3) and the intact seeds (T4) of S. schizophylla showed different patterns of water absorption (Figure 1). The initial moisture content of the diaspores was $19.89 \%$.

Bewley \& Black (1994) reported that the imbibition of seeds starts off with an accelerated uptake of water (Phase I); a physical process that does not depend on the seed viability, as long as there is no physical impermeability. After that, there is certain degree of stabilization in the water uptake (Phase II) and, later on, the seed resumes to actively absorb water at a higher rate (Phase III).

In this research, the water absorption by diaspores and seeds, and the initial gain in mass were relatively fast with an increase of approximately $4.8 \%$ in $\mathrm{T} 1,7.8 \%$ in $\mathrm{T} 2,8.3 \%$ in $\mathrm{T} 3$ and 6.7 in T4, after two hours from the beginning of the test (Figure 1). Nevertheless, phase I imbibition lasted for 72 hours. Carvalho \& Nakagawa (2012) 
reported many species whose phase I lasted for only two hours, followed by phase II, or a period of preparation for reactivation of the metabolism, being considered by Bewley \& Black (1994) as a stationary phase, since a balance between the osmotic potential and the osmotic pressure occurs.

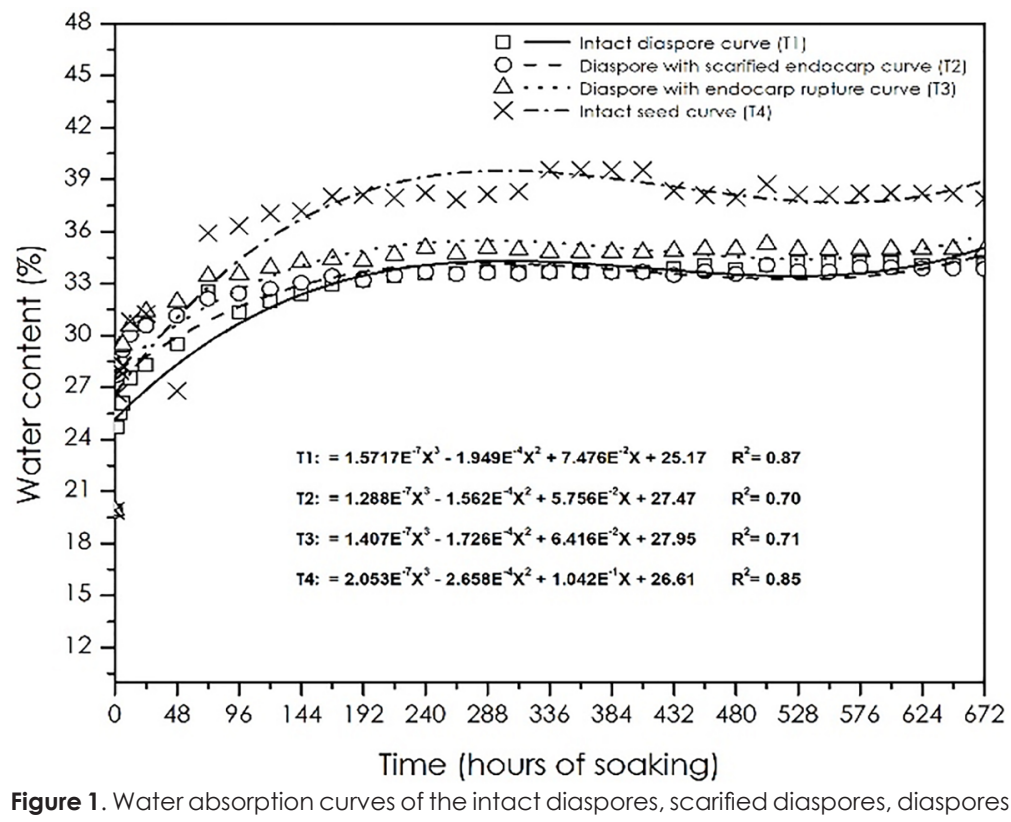

Figure 1. Water absorption curves of the intact diaspores, scarified diaspores, diaspores with endocarp rupture and intact seeds of Syagrus schizophylla.

At the beginning of water absorption, when viable seeds reach 20 to $40 \%$ moisture, many physiological reactions are activated, such as respiration, yield of ATP, mRNA synthesis and DNA repair, as well as synthesis of polysomes and proteins (Bewley \& Black, 1994). The present study observed the initial germination, as evidenced by cotyledon petiole protrusion in $\mathrm{T} 1$ and $\mathrm{T} 2$, on the $18^{\text {th }}$ day (432 hours), and in T3 and T4 on the $12^{\text {th }}$ after the beginning the test (288 hours), characterizing phase III of imbibition.

Notwithstanding, this pattern can vary among species. For example, seeds of Acrocomia aculeata (without endocarp) presented fast water absorption within the first 24 hours and kept stable until the $10^{\text {th }}$ day of imbibition, containing $29.95 \%$ of water (Rubio Neto et al., 2012).

Right from the beginning of phase III, water uptake was actively resumed in all treatments, probably due to the elongation of the embryo axis, characterizing the triphasic imbibition pattern (Bewley \& Black, 1994). The results indicate that both rupture and removal of the endocarp of the diaspores favor water uptake and anticipate the emergence of S. schizophylla seedlings. After 672 hours of imbibition in water the percentage of germination stabilized at $44 \%$ for $\mathrm{T} 1$, $40 \%$ for $\mathrm{T} 2,68 \%$ for $\mathrm{T} 3$ and $56 \%$ for $\mathrm{T} 4$.

According to Carvalho \& Nakagawa (2012), the identification of seed water absorption phases may contribute to the analysis of tegument impermeability and help in experiments based on the duration of treatments with plant regulators, osmotic conditioners and pre-hydration. Pinto et al. (2012) state that the water absorption of Syagrus oleracea seeds depend on the period of time the seeds remain imbibing, affecting both the speed and percentage of germination. On the other hand, Fior et al. (2013) reported that the presence of the endocarp seems not to affect the seed hydration and that the increase in germination percentage might be related to the involuntary tegument scarification during the processing of palm seeds; this is also in contrast to the results in this research which show that germination benefited from the scarification and removal of the endocarp.

The results of the emergence test $S$. schizophylla are shown in Figure 2.

The means of emergence percentages followed the order: $30{ }^{\circ} \mathrm{C}$ (61\%), $25{ }^{\circ} \mathrm{C}$ (53\%) and $25-35{ }^{\circ} \mathrm{C}$ (47\%); but statistical differences were observed only between the emergence percentages of treatments under 30 and $25-35^{\circ} \mathrm{C}$. 


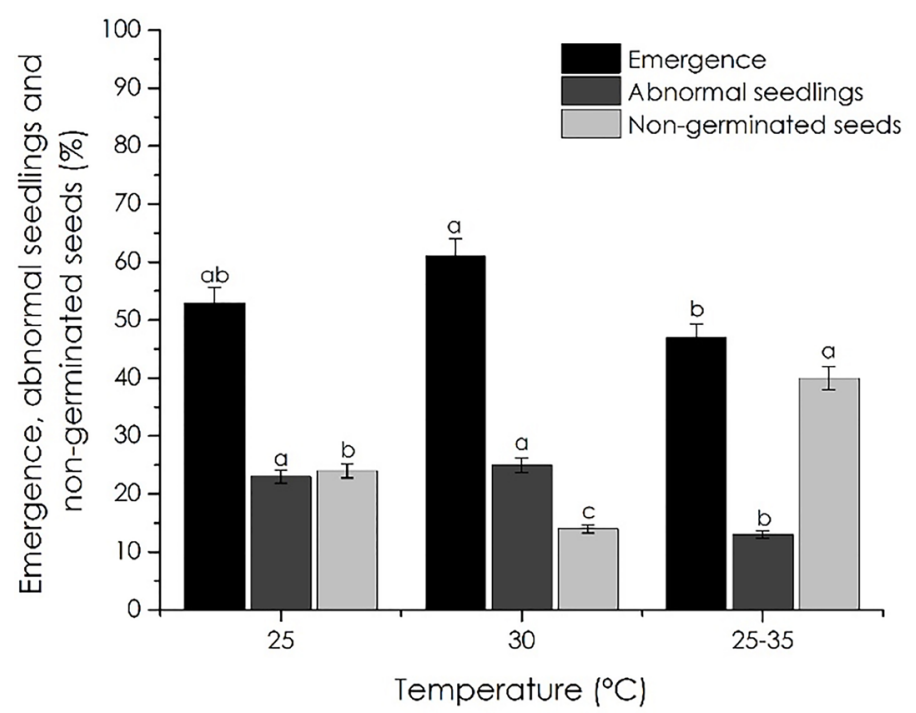

Figure 2. Mean percentages of emergence (normal seedlings), abnormal seedlings and non-germinated seeds (\%) of Syagrus schizophylla at different temperatures. Different letters indicate statistically different means by Tukey test at $5 \%$ probability.

Goudel et al. (2013) studying pregermination treatments on Syagrus romazoffiana seeds also obtained the highest percentage of germination of seedlings at $30^{\circ} \mathrm{C}$. Likewise, Maciel \& Briceño (2009) observed that constant $30{ }^{\circ} \mathrm{C}$ positively affected the emergence of Syagrus stenopetala. Masetto et al. (2012) concluded that the best germination of Copernicia alba was obtained under the alternated temperatures 20 $30{ }^{\circ} \mathrm{C}$ or at constant $30^{\circ} \mathrm{C}$. In contrast, Batista et al. (2011 b) obtained $65 \%$ of emergence of intact seeds of Syagrus oleracea sown in vermiculite with the temperature varying between 23.4 and $28.4^{\circ} \mathrm{C}$. And Teixeira et al. (2011) observed that the constant temperature of $25^{\circ} \mathrm{C}$ was ideal for promoting the emergence of Archontophoenix alexandrae.

In this context, each species has an ideal germination temperature. The temperature can directly affect the germination and the germination speed for interfering in the imbibition of seeds and also in the reactions of mobilization and breaking down reserve molecules necessary during germination, initial growth and development of the seedling (Bewley \& Black, 1994), suggesting that temperatures of constant 25 and $30^{\circ} \mathrm{C}$ are ideal for the emergence of $S$. schizophylla seedlings.

At 25 and $30^{\circ} \mathrm{C}$ the mean percentages of abnormal seedlings were superior (23 and 25 $\%$, respectively) to the one observed with the alternate temperatures $25-35^{\circ} \mathrm{C}$, which was $13 \%$ (Figure 2). In spite of that, at alternate $25-35^{\circ} \mathrm{C}$ there was a significant increase of 26 and $16 \%$ the mean percentages of abnormal seedlings as compared with the percentages observed under the constant temperatures of 25 and 30 ${ }^{\circ} \mathrm{C}$, respectively (Figure 2). These results might be associated to the deterioration of the seeds, thus reducing their capability to generate normal seedlings (Veselova et al., 2015).

Seed deterioration can be characterized as a complex phenomenon of continuous and irreversible physiological changes occurring gradually and progressively during drying, storing and germination (Nagel \& Borner, 2010; Vidigal et al., 2016). This process involves several controlling mechanisms associated to progressive molecular damages. Some reactions may occur even when the seeds have low moisture contents, among which fermentation, oxidation, peroxidation and glycation are most recurrent (Mira et al., 2016; Walters et al., 2010).

These results suggest that alternate temperatures have some negative effects on the growth and development of S. schizophylla seedlings. It has been reported that palm seeds present a certain level of dormancy that can be overcome under specific environmental conditions and pre-germination treatments as reported by Fior et al. (2013) studying seeds of Butia odorata. 
The results of the adjusted emergence

responses to the temperatures used (Figure 3). curve of S. schizophylla made evident different

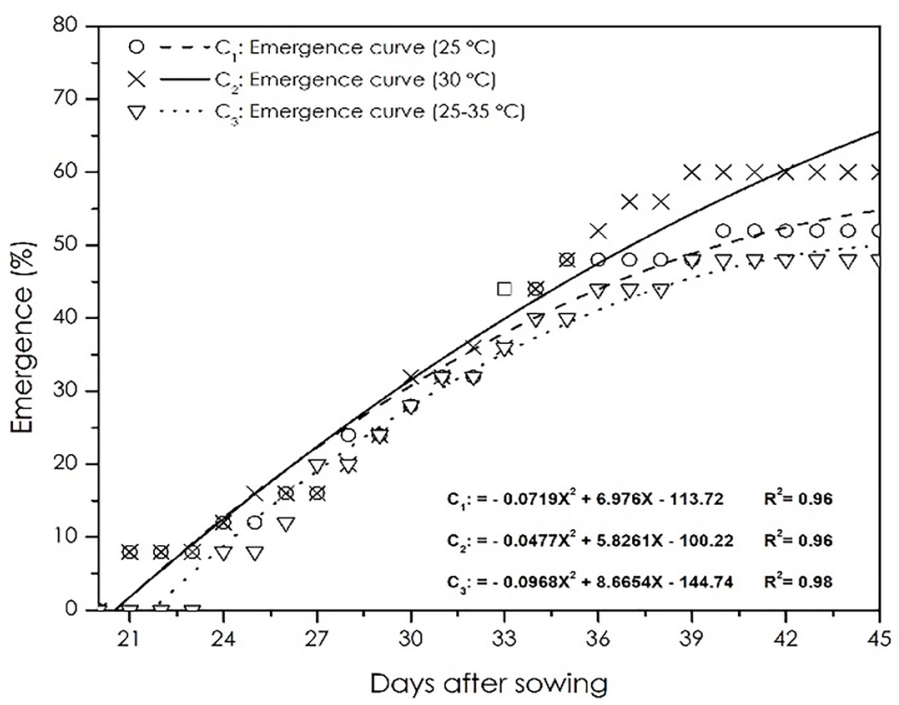

Figure 3. Emergence curve (\%) of Syagrus schizophylla at temperatures of 25 , 30 and $25-35^{\circ} \mathrm{C}$.

The emergence curve presents an increase in the percentage of emerged seedlings regardless of the temperature (Figure 3). Nevertheless, after 36 DAS, the treatment under the constant $30^{\circ} \mathrm{C}$ of temperature showed higher percentages of emergence as compared with the other ones, and emergence stabilized at 39 DAS. No significant difference was observed between emergence percentages under 25 and $30^{\circ} \mathrm{C}$ (Figure 2).

The first germination count was carried out concomitantly with the emergence test, and was the number of germinated seeds at 21 DAS, considering as germinated the diaspores that showed protrusion of the cotyledon petiole.

The highest percentages of germination at first count were obtained under the constant temperatures of 25 and $30^{\circ} \mathrm{C}(8 \%)$ (Figure 4A), followed by $4 \%$ obtained under alternate 25 - $35{ }^{\circ} \mathrm{C}$ (Figure 4), and they differed between themselves.

The mean time of emergence of $S$. schizophylla was statistically the same under all the temperatures studied with an average value of approximately 30 days (Figure 4A). The highest emergence speed index (ESI) was obtained under $30{ }^{\circ} \mathrm{C}$ (0.53) (Figure 4B), and it differed from the ESI obtained at $25(0.44)$ and $25-25^{\circ} \mathrm{C}$ (0.39). Martins et al. (2009) stated that the vigor of seed lots can be estimated by the germination speed index, mean time of germination and by the germination at first count, the reduction of germination speed being a consequence of the deterioration process. Thus, the seed vigor can be understood as the level of energy the seed has for realizing the task of the germination process (Carvalho \& Nakagawa, 2012).

Environmental and biological factors inherent to the physiological quality of seeds and correlated to their production phases, from flowering to harvest, such as temperature, hydric availability, plant nutritional factors, as well as the occurrence of pests and diseases, can affect their vigor either positive or negatively (Marcos Filho, 2005). According to Mengarda \& Lopes (2012), a higher percentage of germination, germination speed index and a shorter germination mean time are associated to a good initial development of seedlings. These indexes generate invaluable information to produce a normal and vigorous stand of seedlings, and are indicative of best physiological quality of seeds (Marcos Filho, 2005).

The diaspores of $S$. schizophylla showed a great variability of shape and size, presenting globose shape with rounded apex and base. The woody endocarp showed brown color exposing the mesocarp fibers adhered to and covering the entire surface, also of brown color (Figure 5A). The dimensions of the diaspores varied from 1.83-3.10 $\mathrm{cm}$ of length and 1.13-1.77 of width (Table 1). 


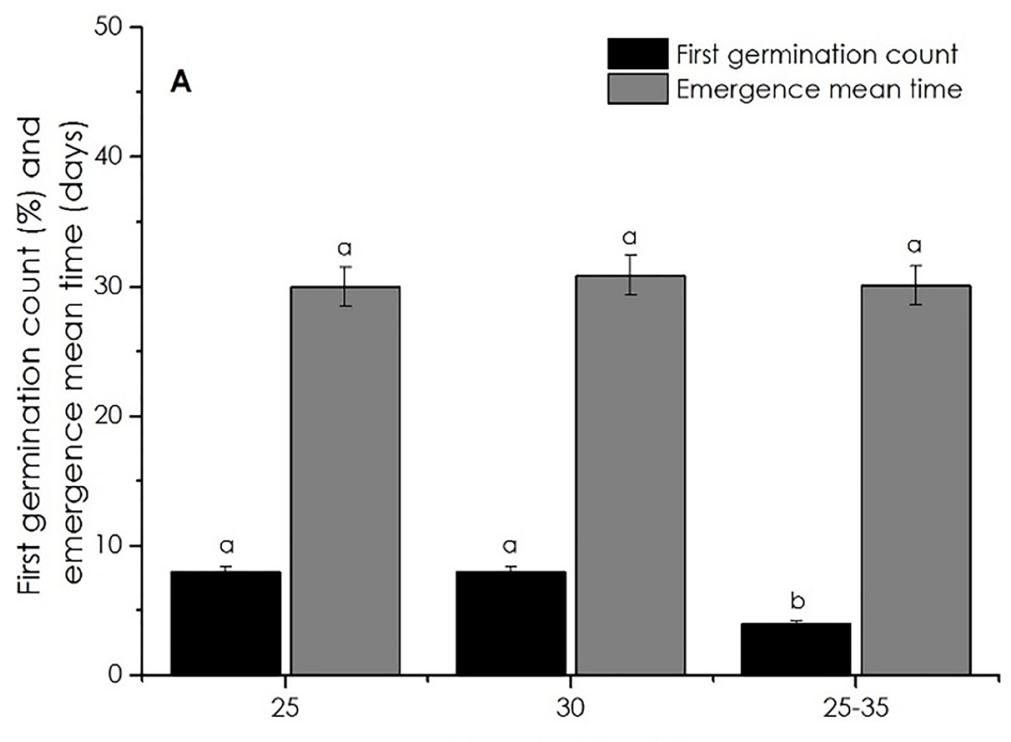

Temperature $\left({ }^{\circ} \mathrm{C}\right)$

Figure 4. First germination count (\%) on the $21^{\text {st }}$ day after sowing, emergence mean time (A) and emergence speed index (B) of Syagrus schizophylla seedlings at different temperatures. Each bar represents the mean percentage of germination at first count, mean time of emergence and the emergence speed index at 25,30 and $25-35^{\circ} \mathrm{C}$. Means with different letters differ statistically by Tukey test at $5 \%$ probability.

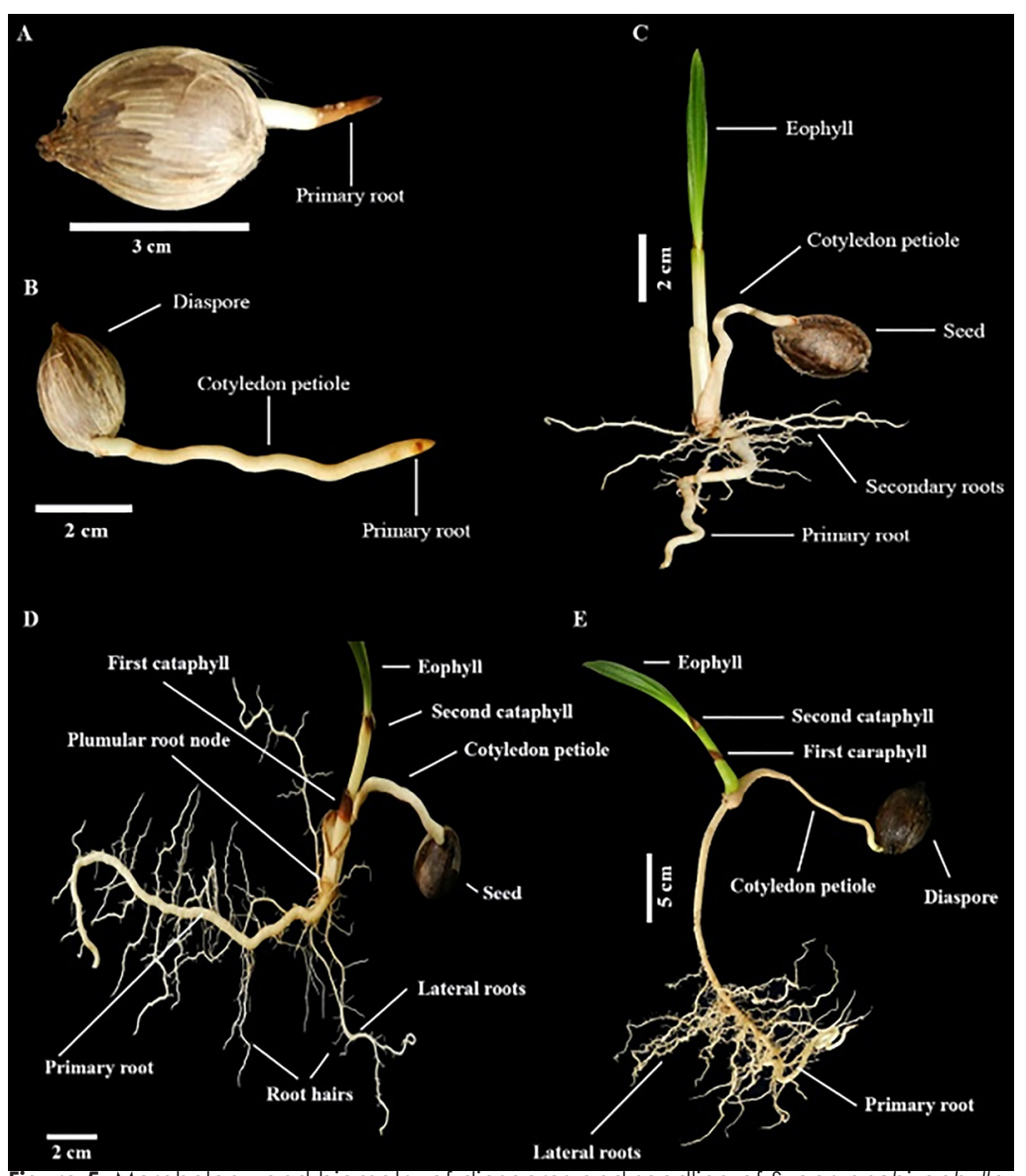

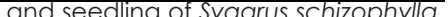
A) External morphology of the diaspore on the $15^{\text {th }}$ day after sowing (DAS). B) External morphology of the diaspore on the $30^{\text {th }}$ DAS. C) Seedling morphology on the $60^{\text {th }}$ day after sowing. D) Seedling root external morphology on the $90^{\text {th }}$ DAS. E) Seedling external morphology on the $90^{\text {th }}$ DAS, showing hypogeal crypto cotyledonal germination of the remote-tubular type. For emergence S. schizophylla seedlings, diaspores were kept in separate BOD growing chambers regulated at constant $30^{\circ} \mathrm{C}$, with a photoperiod $8 / 16$ hours. 
Table 1. Dimensions, standard deviation and coefficient of variation (CV) of the diaspores and seedlings of Syagrus schizophylla on the $60^{\text {th }}$ and $90^{\text {th }}$ days after sowing

\begin{tabular}{|c|c|c|c|c|c|}
\hline \multicolumn{6}{|c|}{ Diaspores of Syagrus schizophylla } \\
\hline$(\mathrm{cm})$ & Maximum & Mean & Minimum & Standard deviation & CV (\%) \\
\hline Length & 3.10 & 2.44 & 1.83 & 0.391 & 16.08 \\
\hline Width & 1.77 & 1.39 & 1.13 & 0.181 & 12.92 \\
\hline \multicolumn{6}{|c|}{ Seedlings of Syagrus schizophylla on the $60^{\text {th }}$ day after sowing } \\
\hline$(\mathrm{mm})$ & Maximum & Mean & Minimum & Standard deviation & CV (\%) \\
\hline$\varnothing$ Main root & 3.20 & 3.09 & 3.03 & 0.048 & 1.56 \\
\hline$\varnothing$ Collar & 3.42 & 3.20 & 3.09 & 0.125 & 3.89 \\
\hline$\varnothing$ Cotyledon petiole & 2.38 & 2.23 & 2.02 & 0.125 & 5.59 \\
\hline Eophyll length $(\mathrm{cm})$ & 7.06 & 6.73 & 6.01 & 0.341 & 5.07 \\
\hline \multicolumn{6}{|c|}{ Seedlings of Syagrus schizophylla on the $90^{\text {th }}$ day after sowing } \\
\hline$(\mathrm{mm})$ & Maximum & Mean & Minimum & Standard deviation & CV (\%) \\
\hline$\varnothing$ Main root & 3.84 & 3.41 & 3.09 & 0.224 & 6.58 \\
\hline$\varnothing$ Collar & 4.45 & 4.13 & 3.79 & 0.202 & 4.90 \\
\hline$\varnothing$ Cotyledon petiole & 1.69 & 1.65 & 1.58 & 0.036 & 2.21 \\
\hline Eophyll length (cm) & 13.44 & 12.08 & 10.88 & 0.605 & 5.01 \\
\hline
\end{tabular}

Legend: diameter $=\varnothing$.

The dimensions of the diaspores can give information about the formation of seed embryos (Carvalho \& Nakagawa, 2012). Larger seeds usually present higher quantities of reserves accumulated their formation and express higher vigor, contain well-formed embryos with higher possibility of originating normal seedlings.

On the $15^{\text {th }}$ DAS, germination began with the protrusion and elongation of the cotyledon petiole, with successive differentiations into primary root, leaf sheath, emerging on the side opposite to the one from where the root emerged, and the first eophyll. These results corroborated the descriptions of Medeiros et al. (2015) for S. coronata.

On the $30^{\text {th }}$ DAS the cotyledon petiole became prominent, cylindrical in structure, with a white-yellowish color (Figure 5B), resembling the primary root and containing the embryo axis, as described by Santos-Moura et al. (2016) for the germination of de S. coronata (Figure 5A-B). Luz et al. (2012) defined the cotyledon petiole of Archontophoenix cunninghamii as a bulbous and hollow structure whose goal is the absorption and translocation of reserves. In A. cunninghamii the cotyledon petiole grew up to 3 when a certain swallowing of its extremity was observed, being this is the region of differentiation and growth of the primary root (Luz et al., 2012), as it was observed in the present research (Figure 5A-B).

On the $60^{\text {th }}$ DAS the cotyledon petiole diameter varied from 2.02 to $2.38 \mathrm{~mm}$ (Table 1) and its color was equivalent to that of the primary root (Figure 5C). Besides, it was observed that the primary, secondary and lateral roots were similar in color, which was white-yellowish, with a marked presence of root hairs. At this stage, the firs expanded eophyll (Figure 5C). The seedlings main roots measured $3.03-3.20 \mathrm{~mm}$ in diameter, the diameter of the collar varied from 3.09 to 3.42 $\mathrm{mm}$ and the eophyll length from 6.01 to $7.06 \mathrm{~cm}$ (Table 1). At this stage the cotyledon petiole and the endocarp are adhered to the seedlings in plain growth and development (Figure 5C), and the seed reserves are still being depleted (SantosMoura et al., 2016).

The germination of S. schizophylla can be classified as hypogeal crypto cotyledonal germination of the remote-tubular type, based in the concept developed by Tomlinson (1961), with the expansion of an absorption organ inside de seed with a further elongation of the cotyledon petiole which leads the seedling to the surface due to the differentiation of the shoot and root primordia (Figure 5-A-B-C). This type of germination may grant an ecological benefit to the survival of $S$. schizophylla under circumstances of water deficit and also against natural predators, since the elongation of the cotyledon petiole and the development of the embryo axis occur far beneath the soil or substrate surface.

Some other palm species have been reported with the same kind of germination 
process as observed in this research. For example, the germination of Syagrus coronata seeds was also described as remote-tubular (Batista et al., 2011 a; Santos-Moura et al., 2016). Nevertheless, Luz et al. (2012) classified the germination of Archontophoenix cunninghamii as adjacent ligular, in which the seedling development happens adjacently to the diaspore.

On the $90^{\text {th }}$ DAS, the main root of seedlings were well developed with fine lateral roots and root hairs as shown in Figure 5D. The color remained white-yellowish. At this stage, a brown color was noticed on the first and second cataphylls. The seedling presented a single lanceolate eophyll measuring 10.88-13.44 cm in length (Table 1) with parallel and longitudinal leaf veins (Figure 5E). The main root diameter was 3.09-3.84 mm, the collar diameter 3.79-4.45 mm and the cotyledon petiole diameter 1.58-1.69 $\mathrm{mm}$ (Table 1).

The standard deviations and the low coefficients of variation of the diaspore and seedling biometric data at 60 and 90 DAS show that they presented homogeneous values, and thus the data can be classified as good, uniform and precise measurements (Table 1).

Studies of morphological and biometric characterization of the dispersion unity, germination and of the seedlings during the initial development may contribute to understanding the biological cycle, as well as to the management and conservation of species (Luz et al., 2012).

\section{Conclusions}

The imbibition of seeds, diaspores with tegument rupture and intact seeds increased and hastened the germination of S. schizophylla.

The temperature of $30^{\circ} \mathrm{C}$ can be used for germinating seeds and obtaining seedlings of S. schizophylla.

The germination of S. schizophylla seeds is hypogeal crypto cotyledonal germination of the remote-tubular type.

The described and illustrated morphological and biometric parameters for $S$. schizophylla are stable and, therefore, reliable for characterizing and identifying the germination of the species.

\section{Acknowledgements}

Thanks to CAPES for granting the graduate study scholarship; and to CNPq for sponsoring the research material.

\section{References}

Baskin, C.C., Baskin, J.M. 2001. Seeds: ecology, biogeography, and evolution of dormancy and germination. New York: Academic Press, 666 p.

Baskin, C.C, Baskin, J.M. 2014. What kind of seed dormancy might palms have? Seed Science Research 24:17-22.

Batista, G.S., Costa, R.S., Gimenes, R., Pivetta, K.F.L., Môro, F.V. 2011 a. Aspectos morfológicos dos diásporos e das plântulas de Syagrus oleracea (Mart.) Becc-Arecaceae. Comunicata Scientiae 2:170-176.

Batista, G.S., Mazzini, R.B., Gimenes, R., Pritchard, H.W., Pivetta, K.F.L. $2011 \mathrm{~b}$. Effects of substrate and mechanical scarification on the germination of Syagrus oleracea (Arecaceae) seeds. Seed Science and Technology 39:649-654.

Bewley, J.D., Black, M. 1994. Seeds: physiology of development and germination. New York: Plenum Press. $445 \mathrm{p}$

Brasil. 2009. Ministério da Agricultura, Pecuária e Abastecimento. Regras para análise de sementes. Brasília. 399 p.

Carvalho, N.M., NAGAGAWA, J. 2012. Sementes: ciência, tecnologia e produção. Jaboticabal: FUNEP, $590 \mathrm{p}$.

Carvalho, V.S., Ribeiro, L.M., Lopes, P.S.N., Agostinho, C.O., Matias, L.J., MercadanteSimões, M.O., Correia, L.N.F. 2015. Dormancy is modulated by seed structures in palms of the cerrado biome. Australian Journal of Botany 63:444-454.

Fior, C.S., De Souza, P.V.D., Schwarz, S.F. 2013. Emergência de plântulas de Butia odorata (Barb. Rodr.) noblick em casa de vegetação. Revista Árvore 37:503-510.

Goudel, F., Shibata, M., Coelho, C.M.M., Miller, P.R.M. 2013. Fruit biometry and seed germination of Syagrus romanzoffiana (Cham.) Glassm. Acta Botanica Brasilica 27:147-154.

Labouriau, L.G. 1983. A germinação das sementes. Washington, USA. $174 \mathrm{p}$.

Leitman, P., Soares, k., Henderson, A., Noblick, L., Martins, R.C. 2015. Syagrus in Flora do Brasil 2020 em construção. Jardim Botânico do Rio de Janeiro. http://www.floradobrasil.jbrj.gov. br/reflora/ floradobrasil/FB15746. <Access on 12 Nov. 2016>. 
Luz, P.B., Pivetta, K.F.L., Neves, L.G., Sobrinho, S.P., Barelli, M.A.A. 2012. Caracterização morfológica do diásporo e da plântula de Archontophoenix cunninghamii (Arecaceae). Comunicata Scientiae 3:244-248.

Maciel, N., Briceño, A. 2009. Effect of fruit ripening, seed scarification and temperature on seedling emergence of Syagrus stenopetala Burret. Revista de la Facultad de Agronomía 26:196-21 1.

Maguire, J.D. 1962. Speeds of germination-aid selection and evaluation for seedling emergence and vigor. Crop Science 2:176-177.

Maia, J., Dekkers, B.J.W., Dolle, M.J., Ligterink, W., Hilhorst, H.W.M. 2014. Abscisic acid (ABA) sensitivity regulates desiccation tolerance in germinated Arabidopsis seeds. The New Phytologyst 203:81-93.

Marcos Filho, J. 2005. Fisiologia de sementes de plantas cultivadas. Piracicaba: FEALQ, 495 p.

Masetto, T.E., Scalon, S.P.Q., Brito, J.Q., Moreira, F.H., Ribeiro, D.M., Rezende, R.K.S. 2012. Germinação e armazenamento de sementes de carandá (Copernicia alba). Cerne 18:541-546.

Martins, C.C., Nakagawa, J., Bovi, M.L. 2009. Avaliação da qualidade fisiológica de sementes de açaí. Revista Brasileira de Fruticultura 31:231235.

Medeiros, M.J., Oliveira, M.T., Willadino, L., Santos, M.G. 2015. Overcoming seed dormancy using gibberellic acid and the performance of young Syagrus coronata plants under severe drought stress and recovery. Plant Physiology and Biochemistry 97:278-286.

Mengarda, L.H.G., Lopes, J.C. 2012. Qualidade de sementes e desenvolvimento inicial de plântulas de pimenta malagueta e sua relação com a posição de coleta de frutos. Revista Brasileira de Sementes 34:644-650.

Mira, S., Hill, L.M., Gonzáles-Benito, M.E., Ibánez, M.A., Walters, C. 2016. Volatile emission in dry seeds as a way to probe chemical reactions during initial asymptomatic deterioration. Journal of Experimental Botany 67:1783-1793.

Nagel, M., Borner, A. 2010. The longevity of crop seeds stored under ambiente conditions. Seed Science Research 20:1-12.

Neves, S.C., Ribeiro, L.M., Cunha, I.R.G., Pimenta, M.A.S., Mercadante-Simões, M.O. 2013. Diaspore structure and germination ecophysiology of the babassu palm (Attalea vitrivir). Flora 208:68-78.

Pinto, J.F.N., Reis, E.F., Netto, A.P.C., Pinto, J.F.N., Assunção, H.F., Nunes, E.F. 2012. Efeito de diferentes tratamentos na superação da dormência de sementes da palmeira Syagrus oleracea Becc. Cerne 18:487-493.

Pivetta, K.F.L., de Paula, R.C., Cintra, G.S., Pedrinho, D.R., Casali, L.P., Pizzeta, P.U.C., Sarzi, I. Pimenta, R. S. 2005. Effects of maturation and scarification on seed germination of Syagrus schizophylla (Mart.) Glass. (Arecaceae). Acta Horticulturae 683:375-378.

Prieto, P.V., Messina, T. Syagrus schizophylla in Lista Vermelha da flora brasileira versão 2012. Centro Nacional de Conservação da Flora. 2012. http://cncflora.jbrj.gov.br/portal/pt-br/profile/ Syagrus schizophylla <Access on 19 Oct. 2016>.

Ribeiro, L.M., Souza, P.P., Rodrigues Jr, A.G., Garcia, Q.S. 2011. Overcoming dormancy in macaw palm diaspores, a tropical species with potential for use as bio-fuel. Seed Science and Technology 39:303-317.

Rubio Neto, A., Silva, F.G., Sales, J.F., Reis, E.F., Silva, M.V.V., Souza, A.L. 2012. Effect of drying and soaking fruits and seeds on germination of macaw palm (Acrocomia aculeata [Jaca.] Loddiges ex Mart.). Acta Scientiarum. Agronomy 34:179-185.

Santos-Moura, S.S., Gonçalves, E.P., Melo, L.D.F.A., Paiva, L.G., Silva, T.M. 2016. Morphology of fruits, diaspores, seeds, seedlings, and saplings of Syagrus coronata (Mart.) Becc. Bioscience Journal 32:652-660.

Teixeira, M.T., Duarte, H.D., Partelli, F.L., Silva, R.F. 2011. Despolpamento, armazenamento e temperatura na germinação de sementes de palmeira real australiana. Pesquisa Agropecuária Tropical 41:378-384.

Tomlinson, P.B. 1960. Essays on the morphology of Palms. Germination and seedling. Principes 4:5661.

Tomlinson, P.B.1961. Anatomy of the Monocotyledons. II. Palmae. In: Metcafe C. R (ed.) The Morphology and Anatomy of Palms. Claredon Press, Oxford, USA. p. 308-311.

Veselova, T.V., Veselovsky, V.A., Obroucheva, N.V. 2015. Deterioration mechanisms in air-dry pea seeds during early aging. Plant Physiology and Biochemistry 87:133-139.

Vidigal, D.S., Willems, L., Arkel, J.V., Dekkers, B.J.W., Hilhorst, H.W.M., Bentsink, L. 2016. Galactinol as marker for seed longevity. Plant Science 246:1 12118.

Viji, V., Ratheesh Chandra, P., Nabeesa Salim., Puthur, J.T. 2015. GerminationAssociated Morphological and Anatomical Changes in Corypha Umbraculifera L. Seeds. Phytomorphology 65:11-17. 
Walters, C., Ballesteros, D., Vertucci, V.A. 2010.

Structural mechanics of seed deterioration:

standing the test of time. Plant Science 179:565-

573. 